\title{
ВПРОВАДЖЕННЯ ОНЛАЙН-КУРСУ ЯК ЕЛЕМЕНТУ ДИСТАНЦИЙНӦ̈ ФОРМИ НАВЧАННЯ У НАВЧАЛЬНИЙ ПРОЦЕС КАФЕДРИ МІКРОБІОЛОГІї, ВІРУСОЛОГІї ТА ІМУНОЛОГІЇ
}

\author{
Zaporizhzhia State Medical University \\ IMPLEMENTATION OF ONLINE COURSE AS AN ELEMENT OF \\ DISTANCE LEARNING IN THE EDUCATIONAL PROCESS OF THE \\ DEPARTMENT OF MICROBIOLOGY, VIROLOGY AND IMMUNOLOGY
}

\begin{abstract}
Мета роботи - розкрити особливості впровадження онлайн-курсу як елементу дистанційної форми навчання у навчальний процес кафедри мікробіології, вірусології та імунології Запорізького державного медичного університету.

Основна частина. У статті висвітлено питання необхідності використання дистанційного навчання як нової інноваційної технології організації освітнього процесу у викладанні дисципліни на кафедрі мікробіології, вірусології та імунології з метою інтенсифікації навчання, тобто передачі великого обсягу навчальної інформації при зниженій кількості аудиторних годин. Проте впровадження дистанційної форми навчання у навчальний процес кафедри є складним багатоаспектним питанням, яке передбачає наявність відповідного навчально-методичного, дидактичного та матеріально-технічного забезпечення.

Висновок. Перехід до сучасних дистанційних технологій навчання, створення умов для їх впровадження, розумне поєднання нових інформаційних технологій навчання з традиційними, формування інформаційної компетентності студентів - складне педагогічне завдання, що потребує розв’язання цілого комплексу психолого-педагогічних, навчально-методичних та організаційних завдань, основними з яких є розробка науково-методичного забезпечення навчально-виховного процесу, інформаційна грамотність викладачів і студентів (уміння орієнтуватись в інформаційному просторі для отримання й оперування інформацією), поширення використання сучасних інформаційних технологій навчання під час викладання предмета у медичному виші.
\end{abstract}

Ключові слова: дистанційна форма навчання; онлайн-курс; мікробіологія.

The aim of the work - to reveal the features of implementing online course as an element of distance learning in the educational process at the Department of Microbiology, Virology and Immunology of Zaporizhzhia State Medical University.

The main body. The article discusses the need to use distance learning as a new innovative technology for organizing the educational process in teaching discipline at the Department of Microbiology and Virology. The main goal is to introduce intensification of training, that is, the transfer of a large volume of educational information with a reduced number of hours. However, the introduction of a distance form of instruction in the educational process of the department is a complex of multifaceted question, which presupposes the existence of appropriate educational, methodical, didactic and logistical support.

Conclusions. The transition to modern distance learning technologies, the creation of conditions for their implementation, the sensible combination of new information technologies of education with traditional ones, the formation of information competence of students is a complex pedagogical task that requires the solution of a whole complex of psychological, pedagogical, teaching, methodological and organizational tasks. The main tasks are the development of scientific and methodological support of the educational process, the information literacy of teachers and students, the dissemination of the use of modern information technologies for teaching in the subject of teaching in a medical university.

Key words: distance education; online course; microbiology.

Вступ. Останнім часом модернізація української системи вищої медичної освіти відбувається в умовах динамічного оновлення інформаційного освітнього простору, імпульсом якого послужили процеси реформування самої системи освіти відповідно до основних положень Болонської декла-

(c) I. O. Топол рації, а саме впровадження європейських норм і стандартів освіти та науки. Як відомо, неперервний професійний розвиток є невід'ємною умовою успішної лікарської діяльності. Якість підготовки майбутніх фахівців багато в чому визначається тією базою знань, умінь і навичок, яка закладається у період навчання студента у медичному виші [2]. 
Тому перед педагогами стоїть завдання покращення якості професійної підготовки майбутніх фахівців, що тісно переплітається з упровадженням сучасних інформаційних технологій і методів навчання, які дають змогу підвищити ефективність освітнього процесу вищого навчального закладу [4].

Мета роботи - розкрити особливості впровадження онлайн-курсу як елементу дистанційної форми навчання у навчальний процес кафедри мікробіології, вірусології та імунологї Запорізького державного медичного університету.

Основна частина. Зміни останніх років у галузі вищої освіти наголосили на контрасті між сформованими традиціями й інноваціями в організації навчального процесу та зумовили необхідність впровадження сучасних інноваційних освітніх технологій для розвитку педагогічного процесу [2]. Однією з них стала технологія дистанційного навчання, що набуває поширення у практиці навчально-виховного процесу у вищих навчальних закладах. Головна мета технології полягає у створенні умов для розвитку професійної компетенції особистості майбутнього фахівця, формування його інформаційної компетентності, стимулювання творчої та самоосвітньої діяльності з поєднанням найкращих традиційних методів та найсучасніших інформаційно-комунікаційних технологій навчання [6]. Як свідчить практика, в даний час пріоритетним напрямом розвитку системи освіти у медичному виші є використання дистанційного навчання 3 метою інтенсифікації навчання, тобто передача великого обсягу навчальної інформації при зниженій кількості аудиторних годин, при цьому якість підготовки майбутніх фахівців зберігається. Проте впровадження дистанційної форми навчання у навчальний процес кафедр є складним багатоаспектним питанням, яке передбачає наявність відповідного навчально-методичного, дидактичного та матеріально-технічного забезпечення [5, 6].

У процесі освіти сучасний студент медичного вишу повинен не тільки акумулювати багаж знань, але й сформувати здатність самостійно шукати і продукувати засоби та способи вирішення проблем, тобто він має бути самостійним та ініціативним. У зв’язку з цим, головною особливістю дистанційної освіти у вищому медичному навчальному закладі є забезпечення доступності навчального матеріалу для самостійного розгляду, і саме візуалізація процесу навчання за допомогою застосування електронних технічних засобів забезпечує якісне засвоєння матеріалу. Слід також зазначити, що застосування цієї технології створює можливості не тільки для “передання” певної інформації від викладача до студента, але й активізує самостійну роботу з використанням інших сучасних освітніх технологій. Тому дистанційна освіта має цілу низку переваг, до яких можна віднести такі: доступність - це можливість займатись у будь-якому місці, де є мережа “Інтернет”; мобільність - це можливість вибору місця навчання незалежно від поточного місця проживання; використання в навчальному процесі новітніх інформаційних технологій; можливість виконувати завдання у зручний для студента час; індивідуальний темп навчання; творчість, розвиток самостійності, самосвідомості.

Однак хотілось б відзначити і недоліки, пов’язані 3 дистанційним навчанням, а саме: психологічні, пов’язані з відсутністю “живого” спілкування з викладачем; відсутністю постійного контролю над студентами, а звідси і високими вимогами до їх самодисципліни, самоорганізації і самоконтролю; неможливістю використання дистанційного навчання при вивченні дисциплін, які потребують обов'язкового засвоєння практичних навичок; необхідністю постійного доступу до джерел інформації. Основа навчання за дистанційною технологією письмова. Тому для деяких студентів відсутність можливості викласти свої знання у словесній формі може перетворитися на “камінь спотикання”. Однак сьогодні розвиток інформаційних технологій дозволяє частково виправити цей недолік за рахунок застосування відеотелеконференцій, вебінарів, за допомогою електронної пошти, технології “Skype”, спілкування в онлайн (on-line) - та офлайн (offline) - режимі - на чатах, форумах, блогах тощо. Ці засоби можуть бути використані як для індивідуальних, так і групових консультацій, спільної роботи, обговорень, презентацій і захисту проектів, наукових робіт.

Слід зазначати, що у вищих медичних навчальних закладах найчастіше використовуються мережеві інформаційно-комунікаційні технології. Серед них найбільшого застосування у дистанційному навчанні набули спеціалізовані інформаційні системи, які отримали назву системи управління навчанням (learning management system, LMS). Зокрема, однією з таких систем, яка впроваджується у Запорізькому державному медичному університеті, виступає система управління навчанням - edX. Навчальний онлайн-курс являє собою електронний комплекс навчально-методичних матеріалів та освітніх послуг, створених для організації індиві- 
дуального та групового навчання з використанням інформаційно-комунікаційних технологій.

Педагогічний процес на кафедрі мікробіології, вірусології та імунології перейшов на рівень, який відповідає вимогам загальних інноваційних технологій. На сучасному етапі розвитку медичного інформаційного суспільства для вдосконалення навчального процесу та підготовки висококваліфікованого лікаря назріла необхідність впровадження дистанційного навчання. Тому уперше з метою впровадження елементу дистанційного навчання при вивченні дисципліни “Мікробіологія, вірусологія, імунологія” викладачі кафедри створили онлайн-курс “Основи імунології”, при розробці якого основну увагу було приділено питанням організації та забезпечення позааудиторної роботи студентів з навчальними матеріалами, адже виділений обсяг аудиторних годин не дозволяє однаковою мірою висвітлити всі розділи програми і провести достатню кількість контрольних тестів. 3 огляду на специфіку предмета, ми вважаємо за доцільне зберегти аудиторні години для практичних занять. Тому важливо правильно організувати позааудиторну роботу. Тобто студентам пропонується традиційні аудиторні заняття поєднувати разом з самостійною роботою в дистанційному курсі. Такий підхід до освоєння змісту курсу сприяє: забезпеченню доступності до навчальних та навчально-методичних матеріалів; зменшенню пропусків занять (пропущені теми можна самостійно вивчити в онлайн-курсі та виконати всі необхідні тестові завдання); реалізації принципу випереджаючого навчання (знайомство з новим матеріалом до аудиторних занять, можливість повторити матеріал до або після занять); створенню гнучкої системи поточного та підсумкового тестування контролю і самоконтролю знань студентів; активізації пізнавальної діяльності студентів (розвиток практичних завдань, виконаних в аудиторії, за рахунок підвищення їх складності узгодженими професійно-спрямованими завданнями); організації онлайн-консультацій. Структура навчального електронного курсу включає такі компоненти, як: визначення теми відкритого онлайн-курсу; виділення основних навчальних елементів відповідно до навчального плану дисципліни; визначення типу відкритого онлайн-курсу (вивчення нової теми, повторення, поглиблення, контроль тощо); вибір найбільш оптимальної за технічними i технологічними особливостями моделі; визначення форми проведення курсу (вебінар, веб-квест, семінар, конференція, лекції тощо); вибір способу доставки навчального матеріалу та інформаційні навчальні матеріали; структуризація навчальних елементів, вибір форми їх пред'явлення студентами (текстові, графічні, медіа, малюнки, таблиці, слайди тощо); використання якісних графічних файлів, оснащених звуковим супроводом і анімацією, підвищують засвоєння матеріалу; підготовка глосарія по тематиці відкритого онлайн-курсу; розробка контрольних завдань для кожного навчального елемента онлайн-курсу; вибір системи оцінювання і формування шкали і критеріїв оцінювання відповідей студентів; підбір списку літератури і посилань на ресурси Інтернету (анотований перелік кращих сайтів 3 даної тематики, сайти електронних бібліотек, журналів), підбір для кожного модуля посилань на внутрішні і зовнішні джерела інформації в мережі “Інтернет” [1].

На першому занятті (організаційний момент) викладач-куратор знайомить студентів з онлайнкурсом, озвучує навчальні цілі, завдання, основні професійні компетентності, передбачені державним освітнім стандартом вищої професійної освіти. В ході вивчення онлайн-курсу студенту пропонується ознайомитися із загальними відомостями про курс, вивчити його розділи, виконати перевірочні роботи і завершити своє навчання, виконавши запропонований підсумковий тест. Після вивчення окремої теми передбачено поточне тестування або рішення різних ситуаційних завдань 3 мікробіології для перевірки та закріплення отриманих студентом знань, що підвищує ефективність їх засвоєння. А такий елемент курсу, як “Електронна лекція” (ЕЛ), дозволяє студенту вивчати навчальний матеріал у цікавій формі, сприяє розвитку його творчого мислення. 3 цією метою в кінці кожної електронної сторінки лекції будуть пропонуватись питання, відповідь на які буде визначати подальше навчання студента. Також слід зазначити, що основним функціональним призначенням кожної ЕЛ $є$ системне концентроване подання нового матеріалу та узагальнення і систематизація попередньо набутих знань. При цьому ЕЛ повинна починатись 3 формулювання чітко визначеної мети та переліку питань, які в ній розглядаються [3].

Корисним і цікавим інструментом електронного курсу є глосарій “Основні терміни і поняття імунології”. Це ефективний засіб для розвитку термінологічного базису у студентів, покликаний допомогти формуванню професійної мови, надзвичайно необхідної майбутньому лікарю [2].

Отже, впровадження дистанційного навчання у вигляді відкритого онлайн-курсу є перспективним 
напрямом педагогічної діяльності викладачів кафедри мікробіології, вірусології та імунології у розвитку професійної компетенції майбутніх фахівців.

Висновок. Перехід до сучасних дистанційних технологій навчання, створення умов для їх впровадження, розумне поєднання нових інформаційних технологій навчання з традиційними, формування інформаційної компетентності студентів - складне педагогічне завдання, що потребує розв'язання цілого комплексу психолого-педагогічних, на-

\section{Список літератури}

1. Журавлёва Л. Открытые онлайн-курсы в работе клинической кафедры высшего медицинского образовательного учреждения / Л. Журавлёва, Н. Лопина // Проблеми та перспективи розвитку науки на початку III тисячоліття у країнах Європи та Азії : тези доп. XII Міжнар. наук.-практ. інтернет-конференції. - Переяслав-Хмельницький, 2016. - С. 148-150.

2. Закон України “Про Основні засади розвитку інформаційного суспільства в Україні на 2007-2015 роки” // Відомості Верховної Ради України (ВВР). - 2007. № 12. - С. 102-109.

3. Комар О. Дистанційне навчання при викладанні курсу “Методика викладання освітньої галузі “Математика”” на факультеті початкової освіти / О. Комар // Пси-

\section{References}

1. Zhuravlieva, L. (2016). Otkrytye onlain-kursy v rabote klinicheskoy kafedry vysshego meditsinskogo obrazovatelnogo uchrezhdeniya [Opened online courses in the clinical department of the higher medical educational institution]. Problemy ta perspektyvy rozvytku nauky na pochatku III-ho tysiacholittia u krainakh Yevropy ta Azii: tezy dopovidei XII Mizhnar. nauk.-prakt. internet-konferentsiia. PereiaslavKhmelnytskyi. (pp. 148-150). [in Ukrainian].

2. Zakon Ukrainy "Pro osnovni zasady rozvytku informatsiinoho suspilstva v Ukraini na 2007-2015 roky” [The Law of Ukraine "On the Basic Principles of Development of Information Society in Ukraine for 2007-2015”]. Vidomosti Verkhovnoi Rady Ukrainy VVR - Information from the Verkhovna Rada of Ukraine, 12, 102-109 [in Ukrainian].

3. Komar, O. (2015). Distantsiine navchannia pry vykladanni kursu Metodyka vykladannia osvitnioi haluzi "Matematyka” na fakulteti pochatkovoi osvity [Distance education when teaching the course "Methodology of teaching the educational branch "Mathematics"”, at the Faculty of Primary Education]. Psykholoho-pedahohichni вчально-методичних та організаційних завдань, основними 3 яких є розробка науково-методичного забезпечення навчально-виховного процесу, інформаційна грамотність викладачів і студентів (уміння орієнтуватись в інформаційному просторі для отримання й оперування інформацією), поширення використання сучасних інформаційних технологій навчання під час викладання предмета у медичному виші.

холого-педагогічні проблеми сільської школи. - 2015. Вип. 52. - С. 115-120.

4. Матвійчук Л. А. Методика впровадження навчальної комп’ютерної програми в навчальний процес підготовки майбутніх інженерів-програмістів / Л. А. Матвійчук // Information Technologies in Education. - 2015. - № 23. C. 60-69.

5. Пойда С. А. Вибір засобів управління самостійною роботою слухачів курсів підвищення кваліфікації учителів інформатики / С. А. Пойда. - Режим доступу : www.umo.edu.ua/images/content/nashi_vydanya/metod_ upr_osvit/v_6/20.pdf.

6. Положення про дистанційне навчання [Електронний ресурс]. - Режим доступу : http://zakon2.rada.gov. ua/laws/show/z0703-13.

problemy silskoi shkoly - Psychological-pedagogical Problems of Rural School, 52, 115-120 [in Ukrainian].

4. Matviychuk, L.A. (2015). Metodyka vprovadzhennia navchalnoi kompiuternoi prohramy $\mathrm{v}$ navchalnyi protses pidhotovky maibutnikh inzheneriv-prohramistiv [Method of introduction of a training computer program into the educational process of the preparation of future engineersprogrammers]. Information Technologies in Education, 23, 60-69 [in Ukrainian].

5. Poida, S.A. (2011). Vybir zasobiv upravlinnia samostiinoiu robotoiu slukhachiv kursiv pidvyshchennia kvalifikatsii ucheteliv informatyky [Selection of means of management of independent work of students of advanced training courses for informatics teachers]. Retrieved from: www.umo.edu.ua/images/content/nashi_vydanya/metod_ upr_osvit/v_6/20.pdf [in Ukrainian].

6. Polozhennia pro dystantsiine navchannia [Regulations on distance learning]. Retrieved from: http://zakon2.rada. gov.ua/laws/show/z0703-13 [in Ukrainian]. 